\title{
THE ROLE OF DR. SHERALI TURDIEV BETWEEN UZBEK AND TATAR LITERARY RELATIONS
}

\author{
Turdieva Khulkar Komilovna \\ ORCID: 0000-0002-0435-8689 \\ Ph.D., Senior Lecturer of Alisher Navoi Tashkent State University of Uzbek Language and Literature, \\ Tashkent, Uzbekistan
}

Article DOI: https://doi.org/10.36713/epra8306 DOI No: 10.36713/epra8306

\begin{abstract}
Uzbek and Tatar nations have had strong literary relations since the beginning of XX century. In building such a good friendly bonds, particular individuals play a significant role with their attempts. Dr. Sherali Turdiev did a lot in the development of literary relations between Uzbek and Tatar nation. It can be proved by his written works also exchanged letters. In this article, request, gratitude and invitation letters by Tatar scholars towards Dr. Sherali Turdiev will be discussed.
\end{abstract}

KEY WORDS: literary relations, correspondences, publication, mutual literary supports

Literary relations are an important process in any nation's spiritual and cultural development of a nation which can be shown by literary translations, literary impact to one another, lively dialogue, and correspondences exchanging letters, scientific and friendly collaborations (meetings, ceremonies, exhibitions, seminars, conferences, congresses and symposiums) as well as mentor-mentee traditions. Literary relations has long been a factor of cooperation and understanding between countries, people and great writers, poets, scholars. Both Uzbek and Tatar nations have had strong bonds in the various fields since long centuries ago. As both nation have the same family of their language, similar cultural principles and the same religion, they have many things in common in the sphere of literature as well. Tatar literature became widespread in Central Asia, Transcaucasia and East Turkestan before the revolution. Starting from 1910-1911 most of the literature and periodicals in Turkestan were published in Tatar language. Before the revolution, various Tatar newspapers and magazines entered Turkestan such as "So'z" (World) from Moscow; "Vaqt" (Time), "Sho'ro" from Orenburg; "Turmush" from Ufa; "Yulduz" (The star); "Quyosh" (The sun) from Kazan had a significant impact on the development of Uzbek literature and periodicals. The works of progressive Tatar poets and writers such as
Gabdulla Tukay, Galimjon Ibragimov, F. Amirkhanov, H.Taktash and others were published regularly. Uzbek writers also participated actively in Tatar journals, publications with their prose and poetic as well as research works and studied at educational establishments named "Madrasai Oliya", "Madrasai Husayniya" and so forth. Besides that, poems and journalistic articles of Tatar and Uzbek writers were published on the pages of newspapers and magazines ("Uchqun", "Sharq", "Inqilob", "Chayan", "Maorif va o'qituvchi", "Ishtirokiyun") in Samarkand and Tashkent (Hamza, S.Avloni, N.Turakulov, A.Qodiriy, A.Sharafutdinov, A.Saadi, S.Ayni and etc. $)^{1}$

Dr. Sherali Turdiev also was keen on Tatar literature and history educations and he had dedicated a big part of his life in studying Tatar literature and contributed quite importantly with his research works, translations, exchanging materials as well as with his disinterested assistance to Tatar researchers.

\footnotetext{
${ }^{1}$ Творческая связи узбекской литературы. Ташкент: Фан, 1983. - С. 73.
} 


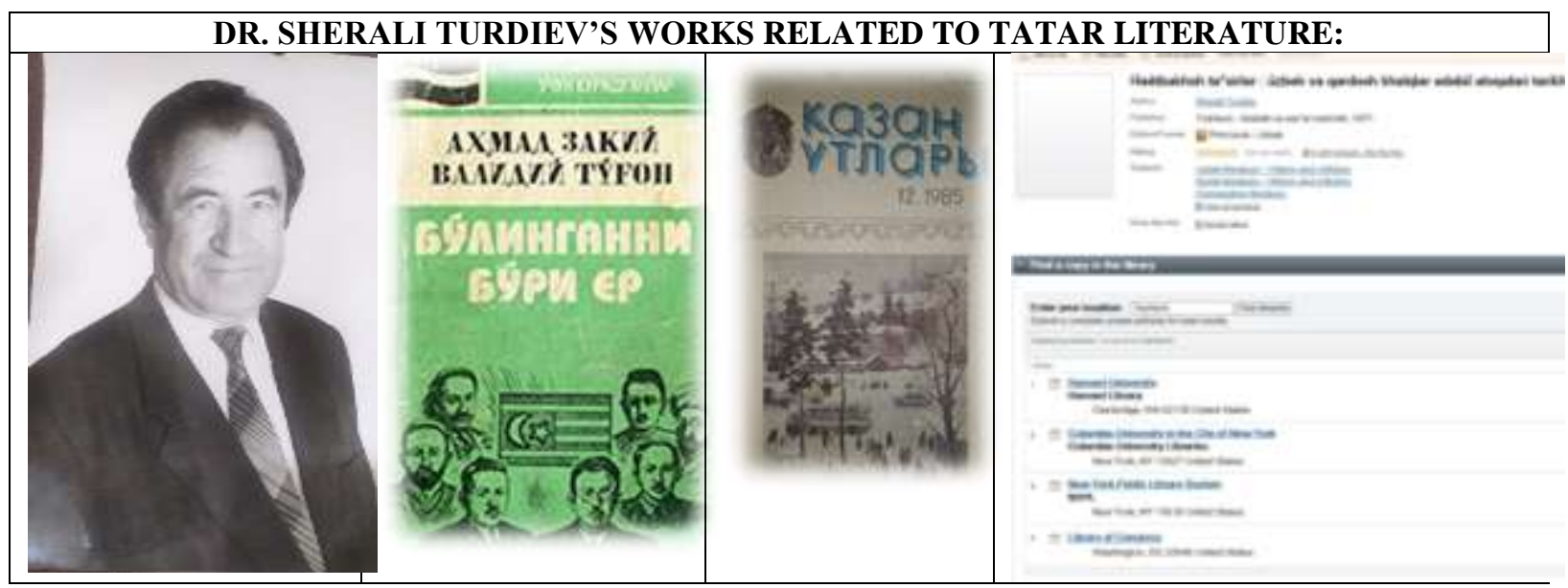

- Ahmad Zaki Validi. Bo'linganni bo'ri yer. (The lone wolf finds trouble) - Book translated by Sherali Turdiev from tatar language into Uzbek.

- Adabiy do'stligimiz tongida. (In the beginning of our everlasting friendship) Book. Tashkent: Uzbekistan, 1974. - 34 p.

- Hayotbaxsh ta'sirlar: o'zbek va qardosh xalqlar adabiy aloqalari tarixidan.

(Vital influences: from the history of literary relations between the Uzbek and fraternal nations) Book. Tashkent: Adabiyot va san'at nashriyoti, 1977. $-105 \mathrm{p}$.

- Adabiy hamkorliklar samarasi: o'zbek-tatar adabiy aloqalari tarixidan. (The results of literary cooperation: from the history of Uzbek-Tatar literary relations) Book. Tashkent: Adabiyot va san'at nashriyoti, 1984. $-126 \mathrm{p}$.

- Гаспиринский и Средняя Азия. Голос Крыма. - 2001. - 23 марта. (Gaspirinsky and Central Asia)

- The activity of Turkestani Jadids as reflected in the records of the Tsarist secret police (1905-1917). Cental Asia on Display. Proceedings of the VII Conference of the European Society for Central Asian Studies, Volume 2, 2005. Vienna. P. 148-153.

- Abdulla To'qay va o'zbek adabiyoti. (Abdulla Tukay and Uzbek literature) Journal “Jahon adabiyoti”, 2011, №4.

- Teran tomirlar. On 100th birthday of Olimjon Ibrohimov (Deep roots). Journal Sharq yulduzi, 1987. N.5. P. 198-200.

- Hamza va qardosh adabiyotlar. (Hamza and fraternal people's Literature) Journal Sharq yulduzi, 1979. N.6. P. 191-194.
- Ismail Gaspirinskiy ve Turkstan (Ismail Gaspirinskiy and Turkestan). Journal Yildiz, Tashkent, 1991. P.13-16.

- Cho'lpon va tatar adabiyoti. (Chulpan and Tatar literature), Journal O'zbek tili va adabiyoti, 1997.N.4. P. 10-14.

- Abdulla Qodiriy va tatar adabiyoti (Abdulla Kadiri and Tatar literature), Journal O'zbek tili va adabiyoti, 1994. N-4-5-6. P.32-38.

- G'afur G'ulom va tatar adabiyoti (Gafur Gulyam and Tatar literature), Journal O'zbek tili va adabiyoti, 2003. N.2. P.32-38.

- Professor Tohir Chig'atoy. Journal O'zbek tili va adabiyoti, 2001. N.1. P.45-48.

- Sadriddin Ayniy va tatar madaniyati. (Sadriddin Ayniy and Tatar culture). Journal O'zbek tili va adabiyoti, 1985. N.4. P.6-11.

- Интернациональные связи литератур Средней Азии с литературами зарубежного востока. (International links of literature in Central Asia with the literatures of the foreign East). Asian and African nations, N. 4. Moscow, 1978. P.128-133.

- Исторические связи литератур народов советского Востока в период 1905-1917. Moscow, 1977. N. 1. P. 90-97.

- Abdulla To'qay O'zbekistonda. (Abdulla Tukay in Uzbekistan), Journal Sharq Yulduzi, 1986. N.4. P.187-191.

- Ahmad Zaki Validi To'g'on. Xotiralar. (Memories). Translation of Sherali Turdiev. Journal Sharq yulduzi, 1993. N.5-6. P 125189.

- Tukay hem uzbek edabiyati. Kazan Utlari. 1985. N.5. P. 121-125.

- G.Ibrahimov hem uzbek edabiyati. Kazan utlari, 1987. N.3. P.58-61. 


\section{EPRA International Journal of Research and Development (IJRD)}

Volume: 6 | Issue: 8 | August 2021

- O'zbek va qardosh xalqlar adabiy aloqalariga doir. Sharq yulduzi, 1963. N.6. P.133-140. (About literary relationships of Uzbek and fraternal nations)

- Hamza Hakimzoda Niyoziy va tatar adabiy aloqalariga doir. (About Hamza Hakimzoda Niyoziy and Tatar literary relationships) Adabiy Meros, Toshkent. 2(36). 1986.

- Ma'rifatparvar va sayyoh. (Enlightener and traveler (About Abdurashid Ibrohimov)). Jahon adabiyoti, May, 2001. P. 137-140.

- Тукай и литература Узбекистана. (Tukay and Literature of Uzbekistan) Zvezda Vostoka. 1986 (5). Tashkent, P.172-177.
Here some part of his works were mentioned. In all his works Sherali Turdiev highlighted the friendly scientific relationship between Uzbek and Tatar scholars.

As a grand-daughter of him, I have an access to read his letters exchanged with international researchers, scholars such as CIS countries (current), Japan, Germany, Austria, The USA, and Turkey.

In this article I am going to focus on the correspondences exchanged between Sherali Turdiev and Tatar researchers. The letters topics can be divided as following: requests, discussions, invitations to scientific events, gratitude and acknowledgements.

Some examples for requests:

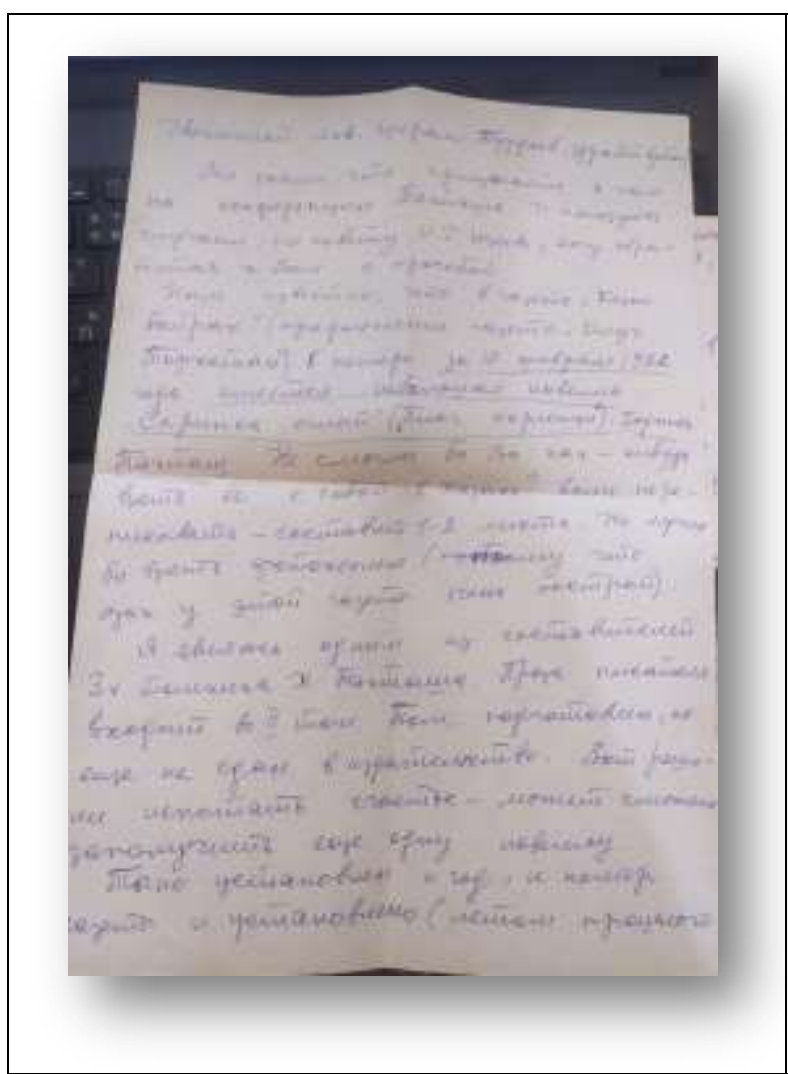

Many researchers, scholars from Tatarstan wrote the letters asking for some assistance as following:

- Books, sources from Uzbekistan State libraries and archives;

- Books, sources from Sherali Turdiev's private archive;

- Asking for advice and consultation in writing Tatar Literature Antology;

- Asking for reviewing particular research works and give his honorable comments and so forth.

Mostly the organizations such as publication offices, research journal editors, libraries, museums, several

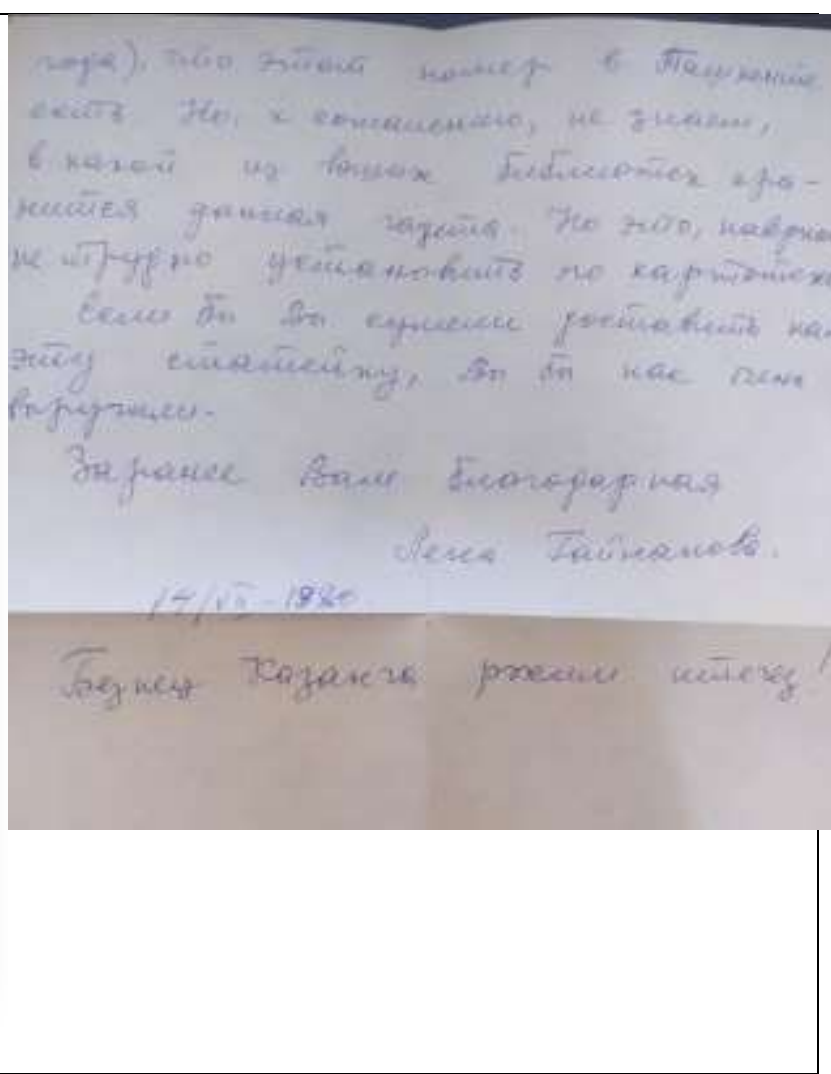

educational establishments, scientific institutions were actively in contact with Dr. Sherali Turdiev.

\section{Thanking Letters}

In his correspondences' archive there are big bunches of thanking letters expressing gratefulness for his significant contribution such as delivering asked materials, photos, archive resources, photocopies original ones of Uzbek literature examples in making books on Tatar literature, organizing events dedicated to Tatar scholars, conducting researches and all were related to Tatar or Uzbek literature and literary relationships. 


\section{EPRA International Journal of Research and Development (IJRD)

Volume: 6 | Issue: 8 | August 2021
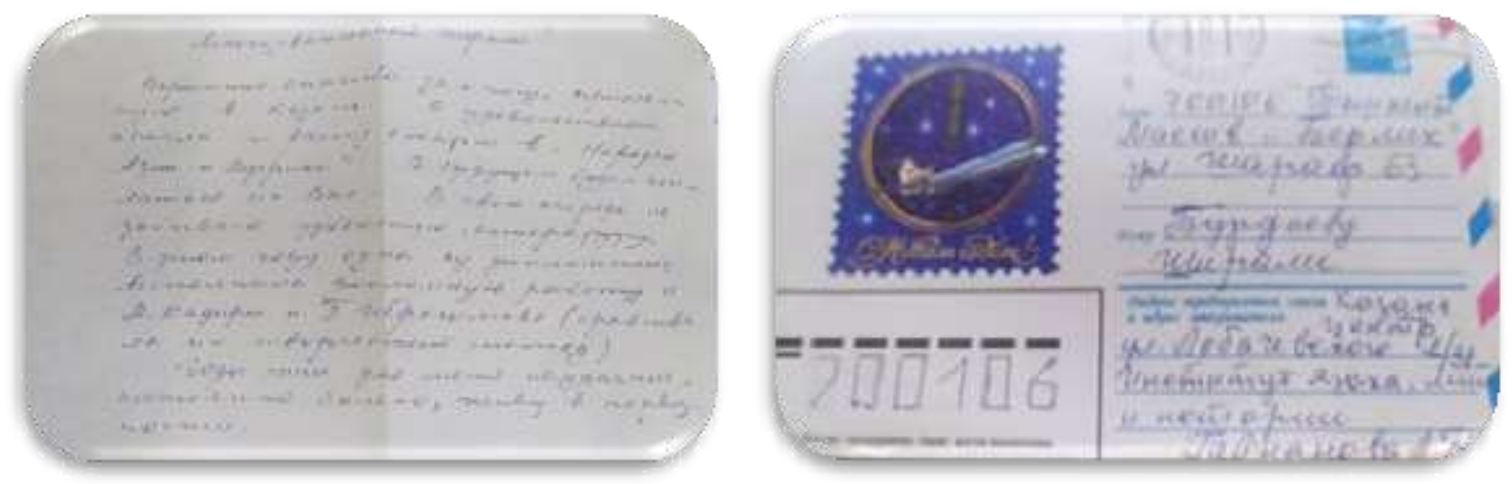

\section{Invitations}
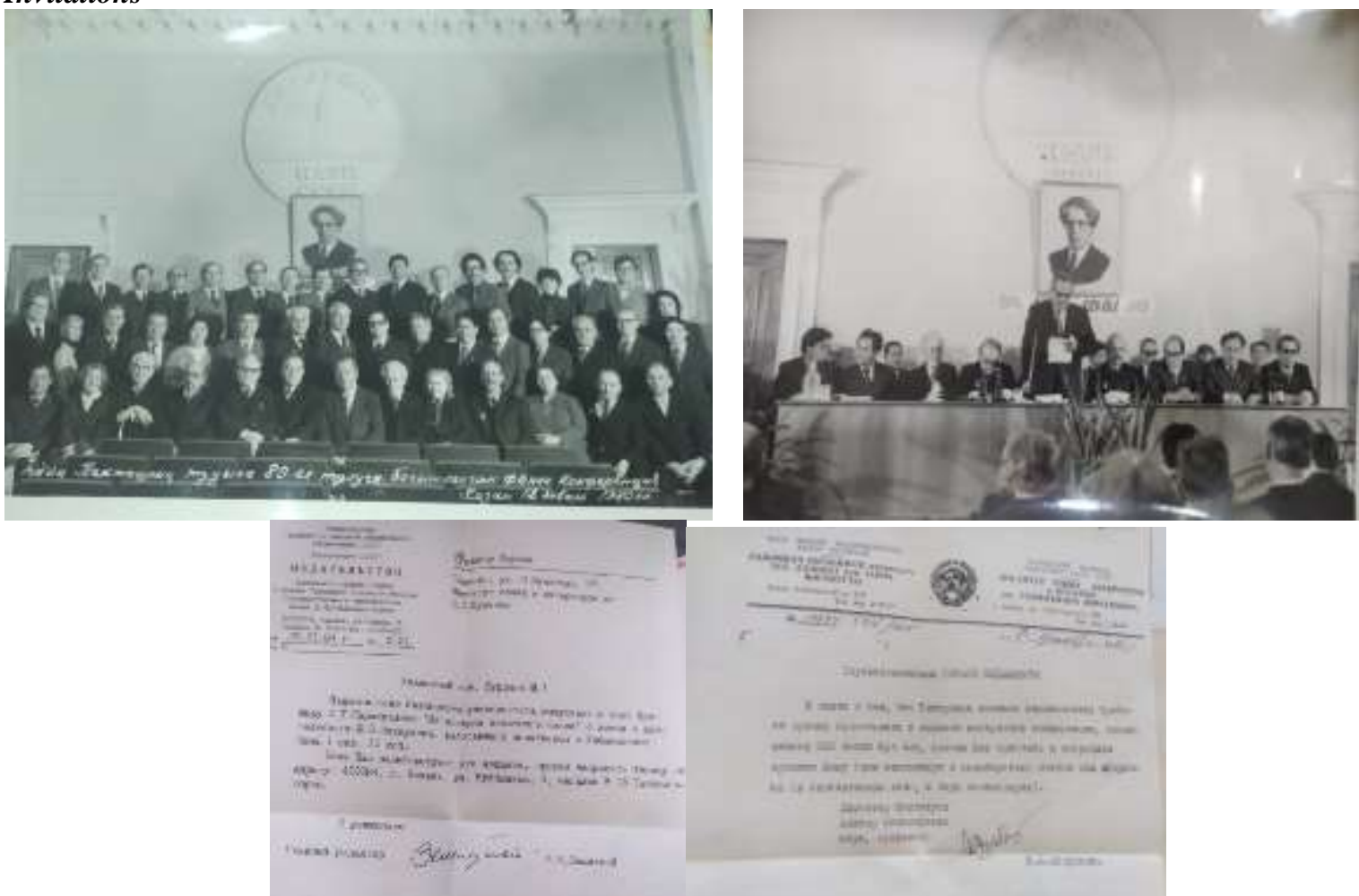

\section{CONCLUSION}

To conclude, Sherali Turdiev can be considered as the scholar who was a bridge of knowledge, scientific and friendly cooperation among many nations. Nowadays, most researches focus on a single object as a research issue. However, Sherali Turdiev did a lot of detailed works on various scholars' works and lives who were from Asian and Western countries. If we collect all his results in one place, it would be a fantastic research for researchers in this sphere.

\section{LITERATURE AND SOURCES}

1. Kazan Utlari. Journal arhives. Tatarstan, Kazan. ( between a period of 1960-2000)

2. Sharq yulduzi, Journal arhives. Tashkent, Uzbekistan. ( between a period of 1960-2011)

3. Jahon adabiyoti. Journal arhives. Tashkent, Uzbekistan. ( between a period of 1960-2011) 